\title{
Chapter 7 \\ Safety and Security Perception as Strategic Issues for Hospitality Companies
}

\author{
Susana Cró \\ IGOT, University of Lisbon, Portugal \& ISAL - Instituto Superior de Administração e Línguas, \\ Portugal \\ Maria de Lurdes Calisto \\ Estoril Higher Institute for Tourism and Hotels Studies, Portugal \\ António Miguel Martins \\ (iD) https://orcid.org/0000-0001-7082-5460 \\ University of Madeira, Portugal \\ José Manuel Simões \\ IGOT, University of Lisbon, Portugal
}

\begin{abstract}
Safety, tranquility, and peace are a necessary condition for prosperous tourism, and security has been identified as one of the five global forces that will drive the tourism industry in the new millennium. Numerous studies have demonstrated that tourism destinations are heavily affected by security perceptions and safety and risk management. In this chapter, the reader may learn about the theoretical models and empirical evidence behind the assertion that security should be seen as a strategic issue not only by tourism destination managers but also by hospitality managers. By the end of the chapter, it will become evident that hospitality managers should take actions in terms of providing their guests higher levels of real and perceived security, as this will be not only ethically right as it will have a positive impact on the company's profitability.
\end{abstract}


Safety and Security Perception as Strategic Issues for Hospitality Companies

\section{INTRODUCTION}

Tourism and security are inevitably interconnected phenomena, as security often emerges as the determining factor in the choice of a given destination (Boakye, 2012; Pizam and Mansfeld, 1996; Sönmez and Graefe, 1998b). In literature, the words 'safety' and 'security' are often used as synonyms, although the two concepts differ in their approach. According to Enz (2009), the concept of 'safety' in hospitality is related to the protection of employees and guests within the limits of the property, against any injuries or deaths. In this way, the concept of 'safety' normally addresses the effects of accidents, hazardous materials, and fires inside the hotel. Among the 'safety' devices that tend to exist in hotels are the fire protection systems, the prohibition of smoking in the rooms, smoke/fire detectors, security cameras, and safety instructions. In turn, the concept of 'security' goes beyond the protection of staff and guests, while also concerned with the safety of guests' property and the security of the hotel itself. This concept includes issues related to robbery and violent crime, thus having a wider scope/coverage. In the present work, the word 'security' refers to its more comprehensive concept.

Security issues related to terrorism, war, crime, political instability and disrespect for human rights tend to constitute barriers to the decision to travel and affect the decision-making of tourist when choosing a destination (Hall et al., 2004; Pizam and Mansfeld, 1996; Saha, Su, and Campbell, 2017). Empirical evidence reveals that a substantial decline in tourist flows tends to happen associated with lack of security in the destination country (Frey, Luechinger, and Stutzer, 2007; Ghaderi, Saboori, and Khoshkam, 2017; Henderson, 2003). In other words, security is an essential prerequisite for the success of the tourist operation as tourists' perception of risk has a significant impact on demand, causing insecure destinations to have difficulty attracting tourists (Seabra, Dolnicar, Abrantes, and Kastenholz, 2013). When tourists feel insecure in the destination country, they tend to develop a bad impression of that destination, and the spreading of that bad image in the various channels of information available on the internet, they can lead to a decline in future tourists (George, 2010).

It is not only terrorist and criminal acts that tend to affect the perceived security risk of a given destination. The violation of human rights also tends to negatively affect the influx of tourists into a country, which might even be greater than the negative effect caused by terrorist acts and political instability. According to Neumayer (2004), the occurrence of terrorist acts in a given country tends to reduce on average the flow of international tourists by $8.8 \%$, while the increase of human rights violations tends to cause a reduction in the flow of tourists in $32 \%$.

The issues regarding security in tourism are most relevant to hospitality managers since tourists and their lodgings are privileged targets for the accomplishment of criminal acts. Crime rate on tourists tends to be higher than that reported for national citizens (Albuquerque and McElroy, 1999; Boakye, 2010; Chesney-Lind and Lind, 1986) and accommodation choice is a crucial factor in explaining crime rates, as half the incidents reported to the authorities occur in these spaces (Barker, Page and Meyer, 2002). Thus, it is not surprising that tourists are willing to pay a premium in terms of price when the accommodation facilities show signs of increased security (Enz, 2009, Feickert, Verma, Plaschka, and Dev, 2006). 


\section{HOW RISK-PERCEPTION AFFECTS TOURISTS' DECISION-MAKING}

Interest in the risk construct began in the 1940s when Knight (1948) suggested risk was a critical component of economic activity. The concept of perceived risk has been introduced to the marketing literature by Bauer (1960, p. 21), as well as the concepts of risk and uncertainty, when he observed "consumer behavior involves risk in the sense that any action of a consumer will produce consequences which he cannot anticipate with anything approximating certainty, and some of which at least are likely to be unpleasant." Perceived risk refers to the individual perception of uncertainty and the negative consequences that may arise from the acquisition of a product (or service), the performance of a given activity, or the choice of a given lifestyle. It is assessed by each individual in a specific context. Peter and Ryan (1976), following Cunningham (1967), proposed a model where risk comprises two dimensions:

Risk $=$ Probability of consequences occurring x Negative consequences of poor choices

The consequences of poor consumer choice in the case of services have long been categorized by Garner (1986) into six categories: social risk (related to how a poor selection will affect in a negative way the perception of other individuals about the purchaser); financial risk (the risk that the service purchased will not attain the best possible monetary gain for the consumer); physical risk (related to any health hazard to the consumer); performance risk (the risk that the service purchased will not be completed in the manner which will result in customer satisfaction); time risk (concerned with the consumer wasting time, loosing convenience or wasting effort in getting a service redone); and, psychological risk (risk associated with how performance of the producer will have a negative effect on the consumer's peace of mind or self-perception). Financial risks (Um, Chon, and Ro, 2006), physical/health risks (Larsen, Brun, Torvald, and Selstad, 2007; Sönmez and Graefe, 1998a,1998b), and social risks (Carter, 1998) have all been suggested as important inhibitors to travel.

Several consumer-buying process models recognize that there are five stages in this process: problem recognition, information search, evaluation of alternatives, purchase decision and post-purchase behavior (see Engel, Blackwell, and Kollat, 1978; Howard and Sheth, 1969; Nicosia, 1966). Risk perception is relevant in all of those phases (Mitchell, 1992).

Tourists tend to compare alternative destinations based not only on typical travel expenses (i.e., travel, accommodation, meals, entertainment) but also other associated costs, including crime or terrorism (Sönmez and Graefe, 1998a). However, most studies focus on perceived risk rather than real risk (Bauer, 1967), as individuals are concerned with only some of the possible outcomes (those related to them) and not so much with total outcomes that can come from the act of consumption (Reisinger and Mavondo, 2005). As an example, see the case reported by Rittichainuwat (2011) that shows that the perceived risk tends to cause more damage in the destination than the real risk. As the author points out, there are destinations that may be physically safe but remain psychologically insecure, such as Phuket, Khao Lak, and Phi Phi Island in Thailand, after the 2004 tsunami.

Media exposure that is given to an event, such as a terrorist act, greatly contributes to risk perception. Media coverage often magnifies the severity of security issues. Not rarely, the coverage of these events is biased, with the real risk of traveling to the destination exacerbated by the coverage of events (Ghaderi et al., 2017), creating a perceived high-risk image of the country in tourists and affecting their choice of destiny. In fact, a significant number of studies in this field reveal how mass media contribute to shaping risk perceptions toward destinations affected by crises, such as criminal activity or terrorism (e.g., Avraham and Ketter, 2008; Rittichainuwat and Chakraborty, 2009; Sönmez, 1998; Weimann and 
Safety and Security Perception as Strategic Issues for Hospitality Companies

Winn, 1994). As Cavlek (2002) pointed out, the public pays more attention to negative news. Therefore, it is important to try to avoid the creation of a harmful picture. By keeping the media constantly up-todate about the actual situation within the country and trying to point out and enhance the destinations' strong points could be the first step towards the reduction of this risk perception.

It is not only terrorist and criminal acts that tend to affect the perceived security risk of a given destination. Neumayer (2004) points out that the violation of human rights also tends to negatively affect the influx of tourists into the country.

Tourists' risk-perception is affected by objective events such a crime, terrorism, and human rights violations but also by individual characteristics. The degree to which each potential tourist is affected by a terrorist act and/or the violation of human rights depends, among other factors, on his attitude and previous experience in terms of international travel, his degree of familiarity with the destination, the level of risk aversion, nationality, age, gender and schooling (Feickert et al., 2006; George, 2010; Lepp and Gibson, 2003). The existence of previous international experience and familiarity with the destiny tends to increase the confidence levels of future trips, despite the possible existence of concerns about terrorist acts and/or human rights violations (Lepp and Gibson, 2003; Sönmez and Graefe, 1998b). Security concerns also tend to decline in tourists with high levels of education. Finally, security concerns tend to be influenced by the level of risk aversion, gender, and the age of the tourist (Feickert et al., 2006; Gibson and Yiannakis, 2002; Plog, 2001, 2002; Sönmez and Graefe, 1998b).

\section{THE RELATION BETWEEN RISK FACTORS AND TOURISM FLOWS}

As a general rule, empirical studies show that crime, terrorism, and political instability have a negative and significant impact on the flow of tourists, and thus on the occupancy rates and rentability of the dwellings. Not infrequently, these events cause a substitution effect and a generalization effect. In fact, the occurrence of these events tends to cause a change in the perception of the risk of the country by the tourist, being seen as a country of high risk, with consequences on the travel plans of the potential tourist - the tourist chooses either a safer destination or postpones the decision to travel to that destination (substitution effect). A generalizing effect often happens as well, since the occurrence of terrorist or criminal acts and/or human rights violations in a given country tends to deteriorate the destination image of countries in the same region. An example of this latter situation is presented in the Neumayer and Plümper (2016) study, which shows that a terrorist attack in an Islamic country where the targets are Western, not only reduces the flow of tourists of the nationalities involved, and of tourists from other western countries, to the country attacked but also to other Islamic countries as well. In spite of these cases, there are situations such as those documented by Wolff and Larsen (2014) in Norway, where a terrorist attack perpetrated by a "lone wolf" has reduced the risk perception of the country (i.e. tourists consider that after this event Norway became a safer country).

Generally, scholars agree that terrorism-related incidents will inevitably cause a significant decline in tourists' intentions to visit terrorism affected destinations (Araña and León, 2008; Krakover, 2005; McKercher and Hui, 2004; Pizam and Mansfeld, 1996; Sönmez, 1998; Sönmez and Graefe, 1998b). However, the effects of terrorism on tourism seem to be stronger in the short term (Liu and Pratt, 2017) than in the long term. On the other hand, the frequency of events has more negative consequences than one event or the severity of the events (Buckley and Klemm, 1993; Pizam and Fleischer, 2002). A transi- 
tory impact on the flow of tourists suggests the long-term sustainability of the tourism sector (Liu and Pratt, 2017; Smyth, Nielsen, and Mishra, 2009). In fact, it seems hotels are significantly affected but quickly recover from the negative effects (Kosová and Enz, 2012). Figure 1 summarizes the impact of terrorist attacks on tourism and hotel companies, as has been suggested in the literature.

In what relates to war and political instability, evidence shows that these circumstances drastically reduced the flow of tourists to the affected countries (Hollier, 1991). Violence related to political instability has an impact on the number of tourists and on the destination's image, as well as on the profitability indicators of hotels and tour operators (Avraham, 2015; Fallon, 2004; Gartner and Shen, 1992; Ivanov, Idzhylova, and Webster, 2016; Neumayer, 2004; Perles-Ribes, Ramón-Rodríguez, Moreno-Izquierdo, and Martí, 2016). Political instability has even a more serious impact on tourist activity than a terrorist attack of low or medium severity (Fletcher and Morakabati, 2008; Saha and Yap, 2014) but similarly, it has a transient effect (Narayan, 2005).

Although some authors (Das and Dirienzo, 2009; Gholipour, Tajaddini, and Al-mulali, 2014; Su and Lin, 2014) include in their empirical analyzes variables related to violations of some human rights (civil

Figure 1. The chain of impacts after one terrorist attack

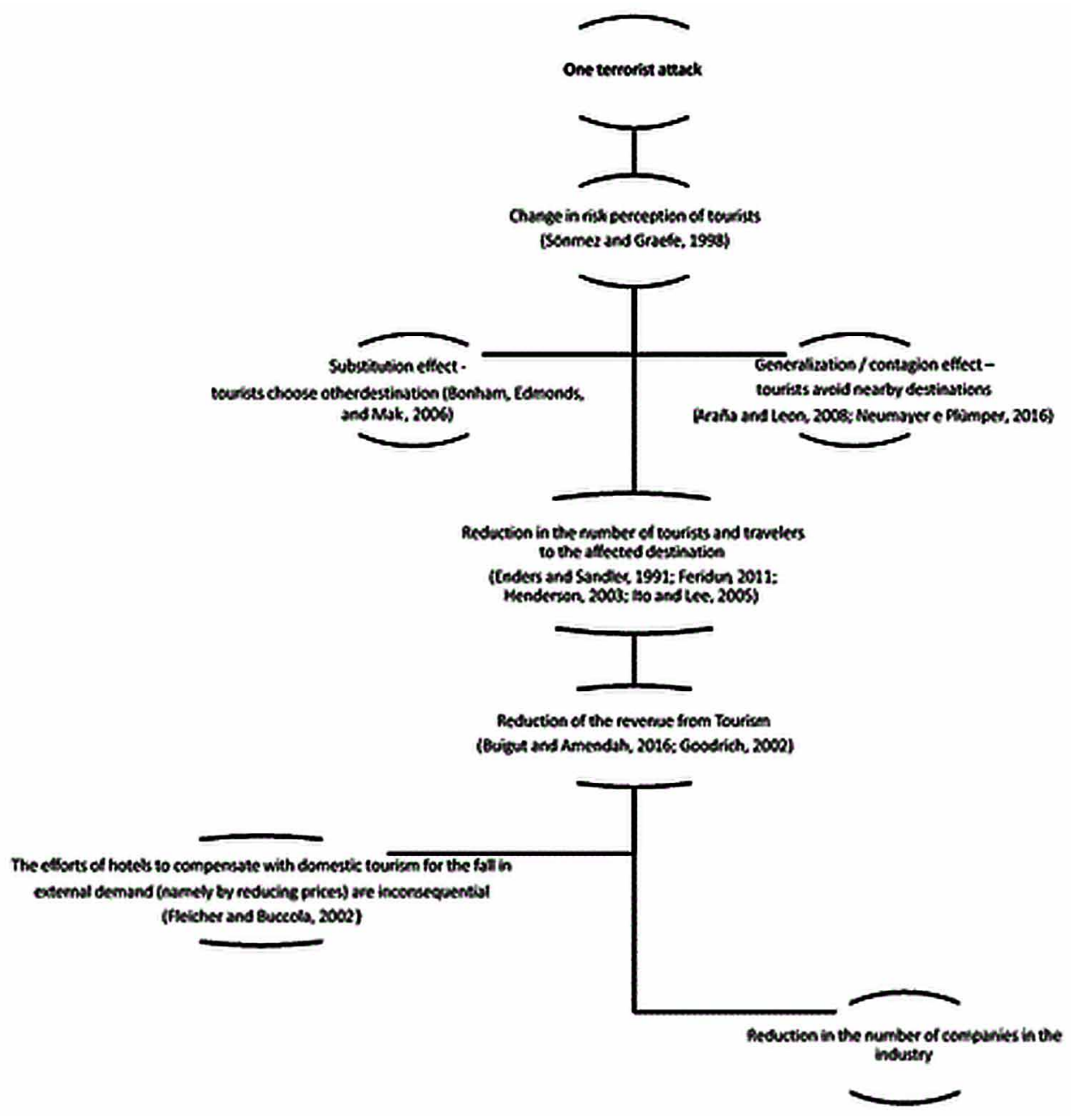


liberties and/or economic freedom), only Saha et al. (2017) provides a theoretical explanation of the impact of human rights violations on the flow of tourists. According to the authors, the negative impact of human rights violations on the flow of tourists to a given destination is due to two reasons: (i) tourists with risk aversion tend to associate countries under dictatorship or non-liberal democracies with a greater risk to their personal security. Tourists fear being judged by an arbitrary, corrupt and ineffective judicial system; (ii) the absence of economic freedom in the country (one of the human rights) tends not to allow entrepreneurs to offer a wide range of tourist products and services, so tourists will tend to choose other destinations due to the offer of poor quality and/or uninteresting services. To these two reasons, one should add another mentioned by Lovelock (2008) - the importance of ethical issues for operators in the supply and marketing of some tourist destinations. The author points out that tourism agencies have some reluctance to offer their clients tourist destinations that are connoted with human rights violations, especially when there are high risks to the personal security of their client. Finally, Callaway and Harrelson-Stephens (2006) point out that there is a close link between human rights violations and terrorist activities. According to the authors, in countries where there is a violation of human rights - such as the right to subsistence, civil and political rights, there is a greater propensity for the development of terrorist actions.

In what concerns crime, the topic has been addressed in literature in two different perspectives - crime as a consequence of tourism (Brunt, Mawby, and Hambly, 2000; Haralambopoulos and Pizam, 1996); and, the negative impact of crime on the flow of tourists (Alleyne and Boxill, 2003).

On the one hand, there is a greater propensity for tourists to be victims of crime, when compared to local residents due to three factors: (i) its appearance - "western look" and its cultural values; (ii) their behavior - on holiday, tourists tend to exhibit a relaxed attitude in terms of security, making them a desirable target in terms of the practice of crime; (iii) the type of environment - tourists tend to frequent unsafe places, which are often not frequented by locals (Boakye, 2010). Chesney-Lind and Lind (1986) too, report that vacationers tend to engage in high-risk activities, such as frequenting nightclubs and bars until late hours, trips to remote and unknown areas or areas considered by residents as dangerous. However, tourists are also exposed to robberies and crimes in accommodation (Albuquerque and McElroy, 1999; Brunt et al., 2000).

On the other hand, the general level of crime in a destination, such as kidnapping, homicide, and sexual crime has an impact on the flow of tourists in both the short and long term (Moyo and Ziramba, 2013). Although tourists' age, nationality, and purpose of visit influence their risk-perception (Adam and Adongo, 2016; George, 2010), crime against property and violence has a negative long-term effect on the tourism sector (Saridakis, Sookram, and Mohammed, 2013).

\section{THE ROLE OF HOSPITALITY MANAGERS}

Following the September 11 terrorist attacks in the United States, the issue of security has received greater attention from the owners and managers of hotel companies and from the users of the services provided by them, as Reisinger and Mavondo (2005) point out. With September 11 there has been a growing perception of the world as a place where life and travel are riskier, which causes the perceived level of 
security of the destination country to be one of the main decisive factors in the choice of a destination country (Kapuściński and Richards, 2016; Sönmez and Graefe, 1998b; Wåhlberg and Sjöberg, 2000). The increase in the frequency of terrorist acts and their harmful effects, together with the high media exposure and negative online comments, highly contributed to constructing this perception.

Tourism-related crisis events have a significant impact on hotel performance measures. For example, Aissa and Goaied (2016) and Sami and Mohamed (2014) show a significant impact of national and international crisis events, such as terrorist attacks on hotel financial performance in Tunisia. Chen (2011) studies the impact of three crisis events - the earthquake on September 21, 1999; the terrorist attacks of September 11, 2001, in the US; and the outbreak of Severe Acute Respiratory Syndrome on April 22, 2003 - on the performance of Taiwanese hotels. The sharp drop in the foreign tourist arrivals caused by the three crises not only weakened hotel revenue but also increased the perceived risk of investment in hotel stocks.

Many of the factors mentioned in the previous section - terrorism, political instability, violation of human rights, are far outside the control of hotel managers. Sometimes collective pressure can be exerted over destination managers and policymakers in terms of reducing the level of risk associated with the country, by taking measures to reduce the levels of crime, political instability and/or terrorism, or by improving respect for human rights. However, the results of those efforts are rarely successful. Even lobbying attempts to revoke advisory travel warnings (concerning arguably unlikely events) issued by governments are unlikely to succeed (Beirman, 2003).

What hotel managers can do, is increase the level of security of their hotels. As the security attribute is an important factor in the selection of accommodation by tourists and plays a key role in shaping meeting planners' site-selection choices (Hilliard and Baloglu, 2008), managers should be a concerned and willing to invest in improving the security systems of lodging facilities. According to Enz and Taylor (2002), safety and security standards are made up of two major elements: (1) physical-safety attributes and (2) organizational systems and plans to ensure a safe operation. The first element, physical attributes, includes the installation of specialized equipment and the provision of materials and information outlining safety and security procedures. The second element, organizational systems and plans, includes employing and training safety and security personnel, and establishing plans and procedures relating to safety and security issues. The authors refer that the safety and security of hotels have become a topof-the-mind matter for hotel guests and managers after the terrible events of September-11, 2001. In response to these concerns, the majority of hotels have created new security procedures, such as conducting more detailed background checks on their employees, the requirement of photo ID on customer check-in or increasing security standards in the parking garages. However, they conclude that customers despite preferring hotels with high standards of safety and security, at the same time they may dislike when such standards cause inconvenience. As a consequence, hotel operators need to strike a sensitive balance between safety and accessible friendly service.

A more recent study shows that hoteliers normally follow local regulations when designing a hotel's safety and security systems (Chan and Lam, 2013) but these authors also investigated the gap between hotel safety and security managers' and hotel guests' perceptions of the relative importance of safety and security facilities. Two sets of questionnaires - designed for managers and guests, respectively - containing 32 attributes were used to gauge respondents' perceptions of different hotel safety and security system installations. The findings reveal that guests perceive "well-equipped fire prevention systems 
in accordance with local regulations", "an emergency plan", "an emergency lighting system", "a 24-h uniformed security guard" and "the regular testing of hotel safety and security systems" to be the top five in-house safety and security systems, whereas hotel managers perceive "closed-circuit television systems for hotel public areas", "emergency lighting systems" and "application of a guest key to activate the lifts to guest floors" to be the third through fifth most important.

Enz (2009) points out that hotels positioned in the higher-priced segments located in urban areas or near airports, and new hotels, tend to maintain high safety standards, and that there is a strong positive correlation between hotel security standards and the price charged. Moreover, crime has a negative and significant impact on hotels operating profitability (Hua and Yang, 2017). Thus, security measures adopted by hospitality companies - namely in less secure locations, for instance by adopting high-tech security systems as well as the staff's ongoing training in security issues (Chan and Lam, 2013; Hua and Yang, 2017), may be seen as a way to differentiate from competitors with significant positive impact on profitability. Concerns about the security of accommodation facilities should be greater in the case of female and older guests, a group for which exceptional safety measures should be created. This group of guests shows availability to pay a higher premium compared to other guests due to the presence of security measures in the accommodation (Cró and Martins, 2017; Cró, Martins, Simões, and Calisto, 2018).

Concerns about security lead many hotel owners and managers to place security devices or to allocate areas/floors for specific types of guests (Chan and Lam, 2013; Yang, Khoo-Lattimore, and Arcodia, 2017). Some luxury hotels have incorporated female-only floors - for instance, the Four Seasons Hotel in Riyadh and the Georgian Court Hotel in Vancouver. The Sofitel in Luxembourg provides high floor rooms for female travelers and room service delivered exclusively by female staff (Voyage, 2014). These strategies aim to provide female travelers with a safe and secure place, though they received criticisms for being discriminatory and superficial because women still have to face the "real" risk when traveling outside the safe hotel rooms (Sathian, 2016). In regions where customers perceive risk as being higher, as in the case of the Middle East, the use of X-ray equipment and metal detectors at the entrance of hotel units tends to be part of the security devices (Chan and Lam, 2013).

According to Cró and Martins (2017) and Cró et al. (2018), safety and security issues are also important in countries perceived as more secure. Cró and Martins (2017) show that security has a significant positive effect on a hostel's premium and average price for a list of European Countries (which includes the most and least safe countries in Europe). However, the impact of security on hostel prices is highest for European countries with the highest crime indexes.

In addition to adopting security measures, the opportunities for marketing communication of hotels and other lodging facilities with high levels of security should be explored. What is pointed out by Björk and Kauppinen-Räisänen (2012: 65) for destinations - "insight into risk dimensions that tourists discuss online enable destination marketers to take action, eliminate factors that cause risk perception, refine destination marketing communication, and build strong brands.", is also relevant for hotel managers. Seabra and colleagues (2013) also point out the need for an adequate marketing mix for the different risk segments, given the heterogeneity in terms of risk perception among international tourists. Risk perception of tourist is influenced by culture and past experience (Ingram, Tabari, and Watthanakhomprathip, 2013; Reisinger and Mavondo, 2006; Rittichainuwat and Chakraborty, 2009; Yechiam, Barron, and Erev, 2005). Another way hotel managers can prevent the problem of crimes committed against tourists, using marketing tools, is through prevention campaigns and policies such as offering all-inclusive packages 
(Alleyne and Boxill, 2003). In addition, research by Hajibaba, Gretzel, Leisch, and Dolnicar (2015) suggests that there are crisis-resilient tourists who are unlikely to be deterred by risky circumstances. Travelers who are somewhat resilient to the type of crises such as terrorism and crime represent viable market segments to explore. On the other hand, group travel is considered to be a preferred option among those seeking to avoid risky situations (Lo, Law, and Cheung 2011).

\section{CONCLUSION}

The security issue has been identified as one of the global forces that will drive the tourism industry in the new millennium. For the consumers of tourism services, safety and security are probably part of the most important aspects regarding the industry. Every risk factor perceived by tourists could be a reason for replacing a destination, or a hotel, by an alternative. Literature has shown that security issues related to terrorism, war, crime, political instability and disrespect for human rights tend to be barriers to travel and tend to affect decision-making in the choice of a given tourist destination, with consequences on the hospitality industry.

The main objective of this chapter is to contribute to the debate on how the risk-perception affects tourists' decision to travel and the effect of safety and security attributes in tourism flows and hospitality companies. Tourists are viewed as rational consumers who must allocate their income between various goods, which include tourist trips. Alteration in travel risks, arising from increased tourist incidents will increase relative prices as perceived by the consumers, given that the consumer will lose time in risk analysis and will increase expenditure on protection. Any increase in terrorist activities directed at one country that places tourists at higher perceived risk would induce a standard substitution effect, as well as a generalization effect.

Empirical studies provide evidence for the negative impact of crime, terrorism, and human rights violations on international tourism arrivals with economic consequences, whatever the type of event. Tourist may simply avoid the affected areas. As the number of inbound tourism arrivals directly impacts the tourism industry, and ultimately the government, especially in countries where tourism is a major contributor to the national economy and fiscal revenue, it is of great importance for policymakers to improve their understanding of how a crisis affects demand. The literature also shows that hospitality managers should be willing to invest in improvements in the safety and security of their properties, given that these are determining factors in the choice of accommodation by tourists. Additionally, properties with high levels of safety and security could charge a price premium which tends to raise sales/earnings and the financial performance of the company. Finally, as highlighted to enhance the profitability of their business, hotel managers should implement and adequate marketing mix strategy for the different risk segments, given the heterogeneity in terms of risk perception among international tourists, where age and gender are factors to be taken into account in the definition of a correct strategy.

The challenge for managers lies in knowing which hotels' safety and security systems are important to hotel guests. Literature reveals that there is a gap between hotel managers' and hotel guests' perceptions of the relative importance of safety and security facilities. Moreover, in spite of the importance given by customers to hotels with high standards of safety and security, at the same time customers may dislike when such standards cause them inconvenience. The challenge lies in making careful choices that provide appropriate standards for safety while not interfering with the hospitality and service levels that customers have come to expect. 
Safety and Security Perception as Strategic Issues for Hospitality Companies

\section{REFERENCES}

Adam, I., \& Adongo, C. (2016). Do Backpackers Suffer Crime? An Empirical Investigation of Crime Perpetrated Against Backpackers in Ghana. Journal of Hospitality and Tourism Management, 27, 60-67. doi:10.1016/j.jhtm.2016.03.003

Aissa, S. B., \& Goaied, M. (2016). Determinants of Tunisian Hotel Profitability: The Role of Managerial Efficiency. Tourism Management, 52, 478-487. doi:10.1016/j.tourman.2015.07.015

Albuquerque, K., \& McElroy, J. (1999). Tourism and Crime in the Caribbean. Annals of Tourism Research, 26(4), 968-984. doi:10.1016/S0160-7383(99)00031-6

Alleyne, D., \& Boxill, I. (2003). The Impact of Crime on Tourist Arrivals in Jamaica. International Journal of Tourism Research, 5(5), 381-391. doi:10.1002/jtr.444

Araña, J., \& León, C. (2008). The Impact of Terrorism on Tourism Demand. Annals of Tourism Research, 35(2), 299-315. doi:10.1016/j.annals.2007.08.003

Avraham, E. (2015). Destination Image Repair during Crisis: Attracting Tourism during the Arab Spring Uprisings. Tourism Management, 47, 224-232. doi:10.1016/j.tourman.2014.10.003

Avraham, E., \& Ketter, E. (2008). Will We Be Safe There? Analysing Strategies for Altering Unsafe Place Images. Place Branding and Public Diplomacy, 4(3), 196-204. doi:10.1057/pb.2008.10

Barker, M., Page, S., \& Meyer, D. (2002). Modeling Tourism Crime: The 2000 America's Cup. Annals of Tourism Research, 29(3), 762-782. doi:10.1016/S0160-7383(01)00079-2

Bauer, R. A. (1960). Consumer Behaviour as Risk Taking. "Dynamic Marketing for a Changing World”, Proceedings of the 43rd conference of the American Marketing Association, 389.

Bauer, R. A. (1967). Consumer Behavior as Risk Taking. In D. Cox (Ed.), Risk Taking and Information Handling in Consumer Behavior (pp. 23-33). Cambridge, MA: Harvard University Press.

Beirman, D. (2003). Restoring Tourism Destinations in Crisis: A Strategic Marketing Approach. CAUTHE 2003: riding the wave of tourism and hospitality research, 1146.

Björk, P., \& Kauppinen-Räisänen, H. (2012). A Netnographic Examination of Travelers' Online Discussions of Risks. Tourism Management Perspectives, 2, 65-71. doi:10.1016/j.tmp.2012.03.003

Boakye, K. (2010). Studying Tourists' Suitability as Crime Targets. Annals of Tourism Research, 37(3), 727-743. doi:10.1016/j.annals.2010.01.002

Boakye, K. (2012). Tourists' Views on Safety and Vulnerability. A Study of Some Selected Towns in Ghana. Tourism Management, 33(2), 327-333. doi:10.1016/j.tourman.2011.03.013

Brunt, P., Mawby, R., \& Hambly, Z. (2000). Tourist Victimisation and the Fear of Crime on Holiday. Tourism Management, 21(4), 417-424. doi:10.1016/S0261-5177(99)00084-9

Buckley, P. J., \& Klemm, M. (1993). The decline of tourism in Northern Ireland: The causes. Tourism Management, 14(3), 184-194. doi:10.1016/0261-5177(93)90019-H 
Callaway, R., \& Harrelson-Stephens, J. (2006). Toward a Theory of Terrorism: Human Security as a Determinant of Terrorism. Studies in Conflict and Terrorism, 29(7), 679-702.doi:10.1080/10576100600701974

Carter, S. (1998). Tourists' and travelers' social construction of Africa and Asia as risky locations. Tourism Management, 19(4), 349-358. doi:10.1016/S0261-5177(98)00032-6

Cavlek, N. (2002). Tour Operators and Destination Safety. Annals of Tourism Research, 29(2), 478-496. doi:10.1016/S0160-7383(01)00067-6

Chan, E., \& Lam, D. (2013). Hotel Safety and Security Systems: Bridging the Gap between Managers and Guests. International Journal of Hospitality Management, 32, 202-216. doi:10.1016/j.ijhm.2012.05.010

Chen, M.H.(2011). The Response of Hotel Performance to International Tourism Development and Crisis Events. International Journal of Hospitality Management, 30(1), 200-212. doi:10.1016/j.jjhm.2010.06.005

Chesney-Lind, M., \& Lind, I. (1986). Visitors as Victims: Crimes against Tourists in Hawaii. Annals of Tourism Research, 13(2), 167-191. doi:10.1016/0160-7383(86)90036-8

Cró, S., \& Martins, A. M. (2017). The Importance of Security for Hostel Price Premiums: European Empirical Evidence. Tourism Management, 60, 159-165. doi:10.1016/j.tourman.2016.11.021

Cró, S., Martins, A. M., Simões, J. M., \& Calisto, M. L. (2018). Effect of Security on Hostels' Price Premiums: A Hedonic Pricing Approach. Cornell Hospitality Quarterly.

Cunningham, S. M. (1967). The Major Dimensions of Perceived Risk. In Risk Taking and Information Handling in Consumer Behaviour. Boston Graduate School of Business Administration, Harvard University Press.

Das, J., \& Dirienzo, C. (2009). Global Tourism Competitiveness and Freedom of the Press: A Nonlinear Relationship. Journal of Tourism Research, 47(4), 470-479.

Enders, W., Sandler, T., \& Parise, G. (1992). An Econometric Analysis of the Impact of Terrorism on Tourism. Kyklos, 45(4), 531-554. doi:10.1111/j.1467-6435.1992.tb02758.x

Engel, J. F., Blackwell, R. D., \& Kollat, P. M. (1978). Consumer Behaviour (3rd ed.). New York, NY: Holt Rinehart and Winston.

Enz, C. (2009). The Physical Safety and Security Features of U.S. Hotels. Cornell Hospitality Quarterly, 50(4), 553-560. doi:10.1177/1938965509345963

Enz, C. A., \& Taylor, M. S. (2002). The Safety and Security of US Hotels a Post-September-11 Report. The Cornell Hotel and Restaurant Administration Quarterly, 43(5), 119-136. doi:10.1016/S00108804(02)80062-3

Fallon, F. (2004). After the Lombok Riots, is Sustainable Tourism Achievable? Journal of Travel \& Tourism Marketing, 15(2-3), 139-158. doi:10.1300/J073v15n02_08

Feickert, J., Verma, R., Plaschka, G., \& Dev, C. (2006). Safeguarding Your Customers: The Guest's View of Hotel Security. The Cornell Hotel and Restaurant Administration Quarterly, 47(3), 224-244. doi: $10.1177 / 0010880406288872$ 
Safety and Security Perception as Strategic Issues for Hospitality Companies

Fletcher, J., \& Morakabati, Y. (2008). Tourism Activity, Terrorism and Political Instability within the Commonwealth: The Cases of Fiji and Kenya. International Journal of Tourism Research, 10(6), 537-556. doi:10.1002/jtr.699

Frey, B., Luechinger, S., \& Stutzer, A. (2007). Calculating Tragedy: Assessing the Costs of Terrorism. Journal of Economic Surveys, 21(1), 1-24. doi:10.1111/j.1467-6419.2007.00505.x

Garner, S. J. (1986, Winter). Perceived Risk and Information Sources in Services Purchasing. The MidAtlantic Journal of Business, 5-15.

Gartner, W., \& Shen, J. (1992). The Impact of Tiananmen Square on China's Tourism Image. Journal of Travel Research, 30(4), 47-52. doi:10.1177/004728759203000407

George, R. (2010). Visitor Perceptions of Crime-Safety and Attitudes towards Risk: The Case of Table Mountain National Park, Cape Town. Tourism Management, 31(6), 806-815. doi:10.1016/j.tourman.2009.08.011

Ghaderi, Z., Saboori, B., \& Khoshkam, M. (2017). Does Security Matter in Tourism Demand? Current Issues in Tourism, 20(6), 552-565. doi:10.1080/13683500.2016.1161603

Gholipour, H., Tajaddini, R., \& Al-mulali, U. (2014). Does Personal Freedom Influence Outbound Tourism? Tourism Management, 41, 19-25. doi:10.1016/j.tourman.2013.08.010

Gibson, H., \& Yiannakis, A. (2002). Tourist Roles: Needs and the Life course. Annals of Tourism Research, 29(2), 358-383. doi:10.1016/S0160-7383(01)00037-8

Hajibaba, H., Gretzel, U., Leisch, F., \& Dolnicar, S. (2015). Crisis-Resistant Tourists. Annals of Tourism Research, 53, 46-60. doi:10.1016/j.annals.2015.04.001

Hall, C., Timothy, D., \& Duval, D. (2004). Security and Terrorism: Towards a New Understanding? Journal of Travel \& Tourism Marketing, 15(2-3), 1-18. doi:10.1300/J073v15n02_01

Haralambopoulos, N., \& Pizam, A. (1996). Perceived Impacts of Tourism: The Case of Samos. Annals of Tourism Research, 23(3), 503-526. doi:10.1016/0160-7383(95)00075-5

Henderson, J. (2003). Terrorism and Tourism: Managing the Consequences of the Bali Bombings. Journal of Travel \& Tourism Marketing, 15(1), 41-58. doi:10.1300/J073v15n01_03

Hilliard, T. W., \& Baloglu, S. (2008). Safety and Security as Part of the Hotel Servicescape for Meeting Planners. Journal of Convention \& Event Tourism, 9(1), 15-34. doi:10.1080/15470140802104557

Hollier, R. (1991). Conflict in the Gulf: Response of the Tourism Industry. Tourism Management, 12(1), 2-4. doi:10.1016/0261-5177(91)90022-L

Howard, J. A., \& Sheth, J. N. (1969). The Theory of Buyer Behaviour. New York, NY: John Wiley \& Sons.

Hua, N., \& Yang, Y. (2017). Systematic Effects of Crime on Hotel Operating Performance. Tourism Management, 60, 257-269. doi:10.1016/j.tourman.2016.11.022 
Ingram, H., Tabari, S., \& Watthanakhomprathip, W. (2013). The Impact of Political Instability on Tourism: Case of Thailand. Worldwide Hospitality and Tourism Themes, 5(1), 92-103. doi:10.1108/17554211311292475

Ivanov, S., Idzhylova, K., \& Webster, C. (2016). Impacts of the Entry of the Autonomous Republic of Crimea into the Russian Federation on its Tourism Industry: An Exploratory Study. Tourism Management, 54, 162-169. doi:10.1016/j.tourman.2015.10.016

Kapuściński, G., \& Richards, B. (2016). News Framing Effects on Destination Risk Perception. Tourism Management, 57, 234-244. doi:10.1016/j.tourman.2016.06.017

Knight, F. (1948). Risk, uncertainty and profit. Boston, MA: Houghton-Mifflin.

Kosová, R., \& Enz, C. (2012). The Terrorist Attacks of 9/11 and the Financial Crisis of 2008: The Impact of External Shocks on U.S. Hotel Performance. Cornell Hospitality Quarterly, 53(4), 308-325. doi:10.1177/1938965512457021

Krakover, S. (2005). Estimating the Effects of Atrocious Events on the Flow of Tourism to Israel. In G. Ashworth \& R. Hartmann (Eds.), Horror and Human Tragedy Revisited: The Management of Sites of Atrocities for Tourism (pp. 183-194). New York: Cognizant Communication.

Larsen, S., Brun, W., Torvald, O., \& Selstad, L. (2007). Subjective food-risk judgments in tourists. Tourism Management, 28(6), 1555-1559. doi:10.1016/j.tourman.2007.02.016

Lepp, A., \& Gibson, H. (2003). Tourist Roles, Perceived Risk and International Tourism. Annals of Tourism Research, 30(3), 606-624. doi:10.1016/S0160-7383(03)00024-0

Liu, A., \& Pratt, S. (2017). Tourism's Vulnerability and Resilience to Terrorism. Tourism Management, 60, 404-417. doi:10.1016/j.tourman.2017.01.001

Lo, A. S., Law, R., \& Cheung, C. (2011). Segmenting Leisure Travelers by Risk Reduction Strategies. Journal of Travel \& Tourism Marketing, 28(8), 828-839. doi:10.1080/10548408.2011.623044

Lovelock, B. (2008). Ethical Travel Decisions: Travel Agents and Human Rights. Annals of Tourism Research, 35(2), 338-358. doi:10.1016/j.annals.2007.08.004

McKercher, B., \& Hui, E. (2004). Terrorism, Economic Uncertainty and Outbound Travel from Hong Kong. Journal of Travel \& Tourism Marketing, 15(2/3), 99-115. doi:10.1300/J073v15n02_06

Mitchell, V.-W. (1992). Understanding Consumers' Behaviour: Can Perceived Risk Theory Help? Management Decision, 30(3), 00251749210013050. doi:10.1108/00251749210013050

Moyo, B., \& Ziramba, E. (2013). The Impact of Crime on Inbound Tourism to South Africa: An Application of the Bounds Test. African Security Review, 22(1), 4-18. doi:10.1080/10246029.2012.737815

Narayan, P. (2005). Did Rabuka's Military Coups Have a Permanent Effect or a Transitory Effect on Tourist Expenditure in Fiji: Evidence from Vogelsang's Structural Break Test. Tourism Management, 26(4), 509-515. doi:10.1016/j.tourman.2003.11.022

Neumayer, E. (2004). The Impact of Political Violence on Tourism: Dynamic Cross-National Estimation. The Journal of Conflict Resolution, 48(2), 259-281. doi:10.1177/0022002703262358 
Safety and Security Perception as Strategic Issues for Hospitality Companies

Neumayer, E., \& Plümper, T. (2016). Spatial Spill-Overs from Terrorism on Tourism: Western Victims in Islamic Destination Countries. Public Choice, 169(3-4), 195-206. doi:10.100711127-016-0359-y

Nicosia, F. M. (1966). Consumer Decision Processes. Prentice-Hall.

Perles-Ribes, J., Ramón-Rodríguez, A., Moreno-Izquierdo, L., \& Martí, M. (2016). Winners and Losers in the Arab Uprisings: A Mediterranean Tourism Perspective. Current Issues in Tourism, 1-20.

Peter, J. P., \& Ryan, M. J. (1976). An Investigation of Perceived Risk at the Brand Level. JMR, Journal of Marketing Research, 13(2), 184-188. doi:10.1177/002224377601300210

Pizam, A., \& Fleischer, A. (2002). Severity versus Frequency of Acts of Terrorism: Which Has a Larger Impact on Tourism Demand? Journal of Travel Research,40(3),337-339. doi:10.1177/0047287502040003011

Pizam, A., \& Mansfeld, Y. (1996). Tourism, Crime and International Security Issues. John Wiley \& Sons.

Plog, S. (2001). Why Destination Areas Rise and Fall in Popularity - An Update of a Cornell Quarterly Classic. The Cornell Hotel and Restaurant Administration Quarterly, 42(3), 13-24. doi:10.1016/S00108804(01)81020-X

Plog, S. (2002). The power of psychographics and the concept of venturesomeness. Journal of Travel Research, 40(3), 244-251. doi:10.1177/004728750204000302

Reisinger, Y., \& Mavondo, F. (2005). Travel Anxiety and Intentions to Travel Internationally: Implications of Travel Risk Perception. Journal of Travel Research, 43(3), 212-225. doi:10.1177/0047287504272017

Reisinger, Y., \& Mavondo, F. (2006). Cultural Differences in Travel Risk Perception. Journal of Travel \& Tourism Marketing, 20(1), 13-31. doi:10.1300/J073v20n01_02

Rittichainuwat, B. (2011). GHOSTS: A Travel Barrier to Tourism Recovery. Annals of Tourism Research, 38(2), 437-459. doi:10.1016/j.annals.2010.10.001

Rittichainuwat, B., \& Chakraborty, G. (2009). Perceived Travel Risks Regarding Terrorism and Disease: The Case of Thailand. Tourism Management, 30(3), 410-418. doi:10.1016/j.tourman.2008.08.001

Saha, S., Su, J., \& Campbell, N. (2017). Does Political and Economic Freedom Matter for Inbound Tourism? A Cross-National Panel Data Estimation. Journal of Travel Research, 56(2), 221-234. doi:10.1177/0047287515627028

Saha, S., \& Yap, G. (2014). The Moderation Effects of Political Instability and Terrorism on Tourism Development: A Cross-Country Panel Analysis. Journal of Travel Research, 53(4), 509-521. doi:10.1177/0047287513496472

Sami, B. A., \& Mohamed, G. (2014). Determinants of Tourism Hotel Profitability in Tunisia. Tourism and Hospitality Research, 14(4), 163-175. doi:10.1177/1467358414543970

Saridakis, G., Sookram, S., \& Mohammed, A. (2013). Does crime deter UK tourists from visiting Trinidad and Tobago? Tourism Economics, 19(4), 959-966. doi:10.5367/te.2013.0229

Sathian, S. (2016). Hotels Should Create Women-Only Floors. Retrieved from http://www. ozy.com/ immodest-proposal/hotels-should-create-women-only-floors/41448 
Seabra, C., Dolnicar, S., Abrantes, J., \& Kastenholz, E. (2013). Heterogeneity in Risk and Safety Perceptions of International Tourists. Tourism Management, 36, 502-510. doi:10.1016/j.tourman.2012.09.008

Smyth, R., Nielsen, I., \& Mishra, V. (2009). I've Been to Bali Too (and I Will Be Going Back): Are Terrorist Shocks to Bali's Tourist Arrivals Permanent or Transitory? Applied Economics, 41(11), 1367-1378. doi:10.1080/00036840601019356

Sönmez, S. (1998a). Tourism, Terrorism and Political Instability. Annals of Tourism Research, 25(2), 416-456. doi:10.1016/S0160-7383(97)00093-5

Sönmez, S., \& Graefe, A. (1998b). Influence of Terrorism Risk on Foreign Tourism Decisions. Annals of Tourism Research, 25(1), 112-144. doi:10.1016/S0160-7383(97)00072-8

Su, Y., \& Lin, H. (2014). Analysis of International Tourist Arrivals Worldwide: The Role of World Heritage Sites. Tourism Management, 40, 46-58. doi:10.1016/j.tourman.2013.04.005

Um, S., Chon, K., \& Ro, Y. (2006). Antecedents of revisit intention. Annals of Tourism Research, 33(4), 1141-1158. doi:10.1016/j.annals.2006.06.003

Voyage, M. (2014). Female Friendly Hotels. Retrieved from https://www.maiden-voyage.com/Hotels.aspx Wåhlberg, A., \& Sjöberg, L. (2000). Risk Perception and the Media. Journal of Risk Research, 3(1), 31-50. doi:10.1080/136698700376699

Weimann, G., \& Winn, C. (1994). The Theater of Terror: Mass Media and International Terrorism. New York: Longman.

Wolff, K., \& Larsen, S. (2014). Can Terrorism Make Us Feel Safer? Risk Perceptions and Worries Before and After the July 22nd Attacks. Annals of Tourism Research, 44, 200-209. doi:10.1016/j.annals.2013.10.003

Yang, E. C. L., Khoo-Lattimore, C., \& Arcodia, C. (2017). A Systematic Literature Review of Risk and Gender Research in Tourism. Tourism Management, 58, 89-100. doi:10.1016/j.tourman.2016.10.011

Yechiam, E., Barron, G., \& Erev, I. (2005). The Role of Personal Experience in Contributing to Different Patterns of Response to Rare Terrorist Attacks. The Journal of Conflict Resolution, 49(3), 430-439. doi: $10.1177 / 0022002704270847$

\section{ADDITIONAL READING}

Aziz, H. (1995). Understanding Attacks on Tourists in Egypt. Tourism Management, 16(2), 91-95. doi:10.1016/0261-5177(94)00016-4

Bonham, C., Edmonds, C., \& Mak, J. (2006). The Impact of 9/11 and Other Terrible Global Events on Tourism in the United States and Hawaii. Journal of Travel Research, 45(1), 99-110. doi: $10.1177 / 0047287506288812$ 
Safety and Security Perception as Strategic Issues for Hospitality Companies

Buigut, S., \& Amendah, D. (2016). Effect of Terrorism on Demand for Tourism in Kenya. Tourism Economics, 22(5), 928-938. doi:10.5367/te.2015.0467

Enders, W., \& Sandler, T. (1991). Causality between Transnational Terrorism and Tourism: The Case of Spain. Studies in Conflict and Terrorism, 14(1), 49-58.

Feridun, M. (2011). Impact of Terrorism on Tourism in Turkey: Empirical Evidence from Turkey. Applied Economics, 43(24), 3349-3354. doi:10.1080/00036841003636268

Fleischer, A., \& Buccola, S. (2002). War, Terror, and the Tourism Market in Israel. Applied Economics, 34(11), 1335-1343. doi:10.1080/00036840110099252

Goodrich, J. (2002). September 11, 2001 Attack on America: A Record of the Immediate Impacts and Reactions in the USA Travel and Tourism Industry. Tourism Management, 23(6), 573-580. doi:10.1016/ S0261-5177(02)00029-8

Ito, H., \& Lee, D. (2005). Assessing the Impact of the September 11 Terrorist Attacks on U.S. Airline Demand. Journal of Economics and Business, 57(1), 75-95. doi:10.1016/j.jeconbus.2004.06.003

Pizam, A., \& Smith, G. (2000). Tourism and Terrorism: A Quantitative Analysis of Major Terrorists Acts and Their Impact on Tourism Destinations. Tourism Economics, 6(2), 123-138. doi:10.5367/000000000101297523 